\title{
GUERRA, V. M. L.; ENEDINO, W. C.; NOLASCO, E. C. (ORGS.). ESTUDOS DE LINGUAGENS: DIVERSIDADE E ENSINO. SÃO CARLOS: PEDRO \& JOÃO EDITORES, 2012. 280P.
}

Resenhado por Willian Diego de Almeida ${ }^{1}$

A obra organizada por Guerra, Enedino e Nolasco, docentespesquisadores da Universidade Federal de Mato Grosso do Sul (UFMS), retrata a importância da língua(gem), do discurso, das literaturas e do processo de ensino-aprendizagem. Com autorespesquisadores nacionais e internacionais, o livro é uma coletânea de textos que primam pela experiência científica heterogênea, pela transdisciplinaridade, por questões sociais, culturais filosóficas e fronteiriças de Estados-nação: campos que (trans)formam e resignificam os sentidos. A obra traz um respeitável prefácio elaborado por Dercir Pedro de Oliveira, Pró-Reitor de Pesquisa e Pós-Graduação da UFMS, antecipando aos leitores os veios que constituem o volume: mistérios da língua, da cultura e da literatura: brechas de pesquisas no campo stricto sensu. A obra é dividida em três partes: a primeira, mais extensa, é composta por 15 artigos; a segunda, dois ensaios; a terceira, uma entrevista.

O primeiro texto, assinado por Abril, traça estudos a respeito das representações mediáticas do despojo da Colômbia mediante Estudos Críticos do Discurso Multimodal. São analisadas nas caricaturas dos periódicos digitais El Espectador e El Tiempo, estratégias discursivas, marcas de resistências e de esteriotipação, características que abrem espaço para a reflexão da relação entre sistemas de signos, conhecimento e cultura. Já no segundo artigo, Guerra problematiza as formas de exclusão que se constituem, via discurso, e se (des)locam na dimensão cultural dos sujeitos

1. Mestrando em Letras pela Universidade Federal de Mato Grosso do Sul, campus de Três Lagoas, e bolsita CAPES. willian.diego@hotmail.com 
indígenas. Ancorada na transdisciplinaridade teórica entre perspectiva discursiva, desconstrução e estudos culturais, a autora denuncia como a construção de identidades se dá por meio de discursos diversos: do colonizador, do colonizado, de fronteiras ideológicas e geográficas. No que se refere ao terceiro artigo, Gentil de Faria aborda que os Estudos da Tradução estabelecem um direcionamento nas leituras de teorias de diferentes lugares do mundo. O que implica dizer que os textos, em especial os da Literatura Comparada, contêm expressões que assumem significados diferentes, sobretudo quando se vê que os sentidos estão também no extralinguístico, no exofórico.

No artigo seguinte, Enedino e Duenha tecem ponderações sobre a peça Mão na Luva, de Odivaldo Vianna Filho, trazendo questões sobre texto, discurso, gênero e construção espaço-temporal, cuja reflexão concede ao leitor a valorização das representações de aspectos sociais e políticos, peças-chave que influenciam a produção teatral. Já no texto de Neves, centrado nas teorias do discurso, da psicanálise e da sociologia, revelam-se representações que constituem o dizer de uma jovem empregada doméstica: marcas de resistência, exclusão, processos de subjetivação feminina. Conclui que as marcas discursivas no dizer da jovem correspondem a condições sócio-históricas, ideológicas e de trabalho. No sexto artigo, Roefero e Reyes, à luz da teoria pós-feminista e teorias queer, estudam as implicações de gênero e denunciam que no discurso narrativo de conto de fadas, clássico ou moderno, há demarcação de estereótipos e de gêneros calcados em uma bagagem falocêntrica, que influem na construção de identidades. No artigo seguinte, Nolasco e Oliveira, com base nos Estudos Culturais, discutem como as condições artístico-culturais são filtradas por discursos atravessados pelo contexto sócio-histórico. O texto assinado por Wagner apresenta as estratégias de polidez, as metas e as formas de negociação advindas do jogo on-line Zoo World, materializadas linguisticamente em posts. A autora ancora-se no conceito-chave de polidez e enfatiza que o jogo desvela, nas mensagens escritas, um endereçamento de como desenvolver os facewants: aspecto crucial 
de uma comunidade de prática jogos sociais on-line. Em seguida, com enfoque nos Estudos Culturais, Nolasco e Kudo fazem uma reflexão a respeito de uma narrativa de Anzaldúa, examinando como a rede de estudos da literatura periférica traz o(s) que estava $(\mathrm{m})$ à margem para o centro, e que há fios discursivos entrelaçados na narrativa: os estudos fronteiriços e direitos político-sociais de um povo que está no liame da dialética inclusão/exclusão.

No décimo artigo, Barbai tem por escopo revelar como a tecnologia constitui o corpo social, o sujeito e o sentido da dimensão material do acontecimento digital, mobilizando as noções de leitura, filiação e construção de sentidos, via análise discursiva de uma webpage, conduzindo a uma ilação: o código de uma língua em HTML não livra o dizer de falhas, visto que é um local de (ins)crição de processos históricos e ideológicos dos sujeitos. Adiante, Lara e Lazarini analisam, por meio da perspectiva discursiva, como anúncios de publicidade de produtos de bebês, em sala de aula, oportunizam e incentivam múltiplas leituras, especialmente pela dinamicidade das estratégias argumentativas, o que permite ao leitor tornar-se mais reflexivo. $\mathrm{O}$ artigo seguinte, assinado por Martins, questiona o papel dos procedimentos enunciativos na construção de sentidos, por intermédio do poema Momento, de Lobivar Matos. Na análise, o autor situa o leitor no contexto semiótico (as bases teóricas) e focaliza o entendimento de como o percurso gerativo de sentido incide na composição do poema. Por conseguinte, o texto de Medina tece considerações a respeito de uma novela mexicana que adapta um fato da vida real a uma narrativa de ficção detetivesca. O autor analisa como uma personagem (re)cria a imagem da Cidade do México, mediante obras plásticas, diários, livros, fotografias e atas de investigação. A seguir, Barros discorre sobre a formação dos educadores de línguas, a partir da análise da produção textual de um aluno do ensino fundamental, enfatizando que há três níveis de reflexão que devem ser ponderados, para um ensino emancipatório que realmente faça diferença na vida de jovens e adolescentes. No décimo quinto artigo, Reis discute a relação entre adolescentes, contexto de reclusão e ensino-aprendizagem do inglês, por meio de excertos de entrevistas e de diários de campo. Postula 
que os discentes assumem a posição de sujeitos-alunos-encarcerados, pelas imagens que fazem de si e do outro, por práticas que mobilizam noções ligadas aos dispositivos de domínio e saber.

$\mathrm{Na}$ segunda parte da obra encontramos dois ensaios. Güell estuda as abrangências das (des)igualdades que imperam em muitos países, em especial no Chile. Articula que o conhecimento que se tem destes valores faz parte das relações sociais, culturais, morais e políticas, legitimando verdades, via manifestação discursiva. No segundo ensaio, Rodríguez e List debatem a questão do trabalho, da vacância e do poder, com base no proposto por Aníbal Quijano. Discorrem que o controle do trabalho se dá por meio do poder capitalista, e que a relação entre trabalho e poder é heterogênea, descontínua e sempre conflitiva, em razão da complexa interação de (inter)grupos sociais.

O último texto da obra, o que fecha a coletânea, trata-se de um diálogo encetado por Guerra com Maria José Coracini, na qual, esta, sintetiza sua experiência como educadora, sua postura crítica em relação às (o)posições teóricas, bem como sua visão sobre o ensinoaprendizagem de línguas materna e estrangeira. Com coerência, Guerra e Coracini criam uma tecitura que adquire novo contorno a cada leitura, construindo, nos interstícios das perguntas e respostas, um breve referencial teórico, de maneira especial no que se refere às práticas educacionais que subjazem aos estudos do discurso, revitalizando as estruturas do saber.

Os organizadores-autores buscaram demonstrar a necessidade de (re)avaliarmos as transformações que têm ocorrido nos regimes academicistas, mediante informações filtradas por posturas críticas e debates significativos, corroborando a necessidade de uma reflexão constante a respeito da linguagem. Seguramente, a obra é direcionada àqueles que se interessam pelas áreas de humanas, sobretudo professores de língua(gen)s, pois se trata de um trabalho sério, resultante de investigações e que esclarece pontos relevantes a respeito do ensino, (inter) discurso, identidade, subjetividade, memória e até cidadania. 